\title{
Alternative Employment of the Rural Population: Areas of Incentives and Ways of Improvement
}

\author{
Fedotova O.A.* \\ Voronezh State Agrarian University named after \\ Emperor Peter the Great \\ Voronezh, Russia \\ Fedotova_vsau@mail.ru \\ Spakhov S.V. \\ Voronezh State Agrarian University named after \\ Emperor Peter the Great \\ Voronezh, Russia \\ ssv78@yandex.ru
}

\author{
Yushkova V.E. \\ Voronezh State Agrarian University named after \\ Emperor Peter the Great \\ Voronezh, Russia \\ madamv88@mail.ru \\ Ageeva O.Yu. \\ Voronezh State Agrarian University named after \\ Emperor Peter the Great \\ Voronezh, Russia \\ ageevaou@yandex.ru
}

\begin{abstract}
Employment of the rural population is one of the crucial problems of the national economy. Under the current conditions, in rural areas, employment is affected by a number of complex and controversial factors - the total number of economically active people, security of village-based enterprises, land, raw materials and material and technical resources, entrepreneurial activities of rural residents and the degree of development of the business environment, production environment and social infrastructure. The decline in rural employment led to structural sectoral mobility, transformed the social structure, and created an informal sector involving a third part of the rural population.
\end{abstract}

Key words - employment; unemployment; labor force; rural tourism.

\section{INTRODUCTION}

The employment sector is a key element in determining the financial and economic crisis. An assessment of available data on the labor market conditions carried out by the Ministry of Health and Social Development of Russia suggests that the negative development of the employment sector in agriculture is more rapid than in the economy of Russia as a whole [5].

There are three main prerequisites for expanding rural unemployment. The first one is the imbalance of supply and demand for labor skilled workers. The second one is a low level of wages. The third one is the lack of non-agricultural activities.

\section{RESULTS AND DISCUSSION}

The consistent reduction in the number of workers involved in agriculture can be analyzed in the context of the increasing scale of production and growing need for auxiliary workers in industrial production [4]. This suggests that agricultural enterprises are adapting to the conditions of the market economy; there is a shortage of skilled workers.

The lack of skilled labor is due to the low level of professionalism and social security which deteriorates quality of working conditions, reduces the size of wages and dubious opportunities for the development of professional skill [11]. As a result, agricultural enterprises are experiencing a shortage of professional workers.

In addition to these problems, the structure and level of employment in the agricultural sector are associated with changes in the functions of local governments. They do not have capabilities and reserves to ensure their own development. This factor reduces the number of social programs in rural areas, decreases the number of employed people and deteriorates the balance in the labor market in rural areas.

The problem of unemployment in the agricultural sector is associated with the transition period:

- complication of the financial and economic situation makes it difficult to maintain and increase production rates.

- the unequal ratio of job cuts to the increasing supply. The proposal is carried out through the release of workers rather than through the hiring of skilled ones.

- one of the negative aspects is the unemployment benefit, calculated by the average level of wages; in the rural sector, it is not high.

The agro-industrial complex is a mono-industrial labor sphere, which indicates the limitation of the types of activities, which reduces the availability of jobs. As a result, the basis for the growth of unemployment was a decrease in production and a decrease in employment.

From March 4 to July 28, 2017, the number of enterprises in the agricultural sector increased 4.4 times, and amounted to $8.9 \%$. The number of unemployed increased by 3 times, although for all economic activities it increased 1.8 times.

The number of reduced farm workers increased 5.1 times, and the number of removed ones -5.5 times. The relationship can be explained by the fact that in agriculture there was a 
deep procedure for transferring excess labor to stock due to reduced working hours and unpaid leaves [9].

These actions reduced the number of dismissed workers and decreased the employment rate.

For example, in 2017, the number of employees of agricultural enterprises who did not work due to the fault of employers increased 8 times, the number of part-time workers increased 6 times. Over the past year, the number of employees who were granted administrative leaves has doubled.

The artificial maintenance of the low unemployment rate negatively affects the income level of agricultural workers the number of employees who were granted unpaid leaves was $18 \%$. Moreover, the real wage is much lower than its average level in the national economy. Today, a quarter of Russian citizens are in worse living conditions than the rest. This reflection of social inequality can lead to chronic imbalances in the labor market.

The manifestations of layoffs and hidden unemployment significantly decreased in 2018, when the financial and economic situation stabilized. In agricultural organizations, these processes are gradual (Table 1).

TABLE I. FORCED UNDEREMPLOYMENT IN ORGANIZATIONS OF THE RUSSIAN FEDERATION INVOLVED IN THE LABOR MARKET MONITORING, THOUSAND PEOPLE [7]

\begin{tabular}{|l|l|l|l|}
\hline \multicolumn{1}{|c|}{ Parameters } & \multicolumn{1}{|c|}{$\mathbf{4 . 0 3 . 2 0 1 7}$} & $\mathbf{3 0 . 1 2 . 2 0 1 8}$ & $\mathbf{2 8 . 0 7 . 2 0 1 9}$ \\
\hline $\begin{array}{l}\text { Total number of employees } \\
\text { who do not work due to the } \\
\text { fault of employers }\end{array}$ & 209.4 & 202.0 & 69.8 \\
\hline $\begin{array}{l}\text { of which in agricultural } \\
\text { organizations }\end{array}$ & 0.3 & 2.5 & 1.8 \\
\hline $\begin{array}{l}\text { Total number of employees } \\
\text { who work part-time at the } \\
\text { initiative of the } \\
\text { administration }\end{array}$ & 75.5 & 1296.9 & 598.4 \\
\hline $\begin{array}{l}\text { of which in agricultural } \\
\text { organizations }\end{array}$ & 9.8 & 56.4 & 40.7 \\
\hline $\begin{array}{l}\text { Total number of employees } \\
\text { who were granted a leave at } \\
\text { the initiative of the } \\
\text { administration }\end{array}$ & 87.2 & 149.2 & 48.1 \\
\hline $\begin{array}{l}\text { of which in agricultural } \\
\text { organizations }\end{array}$ & 3.2 & 6.0 & 4.8 \\
\hline
\end{tabular}

From 2018 to 2019, the unemployment growth rate in rural and urban areas varied significantly. The poverty level in the rural area was significantly lower than in urban areas. If the number of unemployed economically active citizens increased by $45 \%$, an increase in the number of unemployed rural residents amounted to only $18.7 \%$. Unfortunately, with a more objective accounting of the unemployed in rural areas, the problem of job shortage is becoming much more relevant, and its solution will become much more complicated.
TABLE II. THE NUMBER OF UNEMPLOYED AND THE GENERAL UNEMPLOYMENT RATE FOR THE ECONOMICALLY ACTIVE AGE POPULATION (AVERAGE) [7]

\begin{tabular}{|l|l|l|}
\hline \multicolumn{1}{|c|}{ Parameters } & \multicolumn{1}{|c|}{$\begin{array}{c}\text { Unemployed, } \\
\text { thousand people }\end{array}$} & $\begin{array}{c}\text { Unemployment rate, } \\
\%\end{array}$ \\
\hline Urban population & 5.2 \\
\hline 2017 & 2979 & 7.6 \\
\hline 2018 & 4219 & 9.6 \\
\hline Rural population & 1813 & 11.2 \\
\hline 2017 & 2154 & \\
\hline 2018 &
\end{tabular}

The data in Table 2 indicate that the unemployment rate in rural areas is 1.5 times higher than in cities. In the reporting year, the total number of unemployed living in rural areas increased from 1.9 million to 2.2 million. The economically active rural population (aged 15-72) is above the threshold, which is $10 \%$. In 2018, this indicator amounted to $11.2 \%$, while in cities it was $7.6 \%$. Among the negative consequences of the current situation in rural areas, there is a threat of social instability. According to the surveys conducted in 34 regions, the share of rural people who are afraid of losing their jobs has grown from $47 \%$ in 2017 to $52.7 \%$ in 2018. In 2019, it exceeded $66 \%$.

In the youth labor market, the unemployment rate is much higher [12]. This is due to the low competitiveness of young people as a result of which part of the population aged 16-29 years is unemployed or employed in the informal sector of the economy. Another cause is the lack of demand for some professions acquired by young specialists.

Since 2017, the Rosstat has been conducting a sample study of the labor force aged 15 years and older. According to the data obtained, the employment rate in the age groups 16-19 was $6.7 \%, 20-25-52.5 \%, 26-29-82.2 \%$; in 2018, the share of unemployed aged 15-19 was 5.7\%, 20-24 $51.7 \%, 25-29-82.3 \%$.

According to the Federal State Statistics Service, in 2017-2018, the level of employment increased in the age group 16-19 and decreased in the age group 20-25. It increased in the age group $26-29$ by $0.3 \%$ [7].

The unemployment rate increased from 26.1 to $30 \%$ for people aged 16-19 and decreased for people aged 20-25 from 12.5 to $12.3 \%$. It decreased $\mathrm{m}$ from 6.1 to $5.5 \%$ for people aged 26-29.

At the end of 2019, the share of people aged 25 was $23.7 \%$ of the total number of unemployed, including $4.6 \%$ in the age group of 16 to 19 and $19.1 \%$ in the age group of 20-25. The maximum value of this indicator was observed for young people aged 16-19 (35.3\%) and 20-25 (14.2\%) [7].

The problem of employment in rural areas is very acute. To solve it, it is necessary to develop all areas that contribute to the creation of productive working conditions [1]. One of these areas is the implementation of the "State Program for the Development of Agriculture and regulation of agricultural markets, raw materials and food for 2013-2020." It is necessary to develop similar regional programs in order to calculate the required number of jobs in terms of their 
vocational qualifications structure. Excessive labor should be redistributed into alternative areas.

The harmonious development of rural areas is one of the most important factors for the sustainability of the Russian economy [3]. With the modernization of agricultural production and growing labor productivity, a decrease in the rural employment rate is becoming inevitable. To preserve the village as a subsystem of society, performing production and other important functions, it is necessary to diversify the economy, stimulating strengths of the city-village connection.

To support the agricultural sector, for 2020, 319.5 billion federal budget rubles were allocated. In 2019, this figure amounted to 318.2 billion rubles.

The largest share of funds - $32 \%$ - was soft loans (90.9 billion rubles). $22 \%$ were allocated for transfers between budgets, including "compensation" subsidies 34.2 billion rubles and "stimulating" subsidies -27.1 billion rubles. $12 \%$ of the allocated money or 33.8 billion rubles will support agricultural exports, 30.2 billion rubles will be allocated for investment loans [9].

Taking into account that the indicators are increasing, a significant impetus is needed to resolve this issue. Certain measures to support agricultural enterprises were provided for in the special program for the sustainable development of rural areas until 2020. This program was developed by the Center for Social Policy and Village Development Monitoring in 2019.

According to the program, in order to support agricultural producers, it is necessary to take the following measures:

- to increase the number of recipients of credit resources allocated to finance non-agricultural enterprises in rural areas;

- full or partial exemption from fees and duties for agricultural enterprises;

- construction and commissioning of sanatoriums, rest houses, tourist camps for agricultural workers;

- appropriate legislative support.

It is important to provide benefits for workers who find it difficult to find a job or are unemployed.

One of the goals of the state agrarian policy is the development of small and medium enterprises in rural areas, including agritourism. Peasant farmers will receive additional income from a new type of economic services - domestic tourism.

Rural tourism is a type of tourism whose main feature is the staying of guests in the countryside, away from industrial enterprises, closer to nature. Tourists come to the village in order to take a break from the hustle and bustle of the city, learn something new about life in the hinterland, local traditions and something new about agricultural production [13].

The Concept for the development of rural tourism in Russia determines the methods for the development of agritourism until 2030, taking into account the concept of long-term socio-economic development of the Russian Federation for the period up to 2020.

The development of rural tourism is crucial for developing rural areas. This is determined by the following factors:

- an increase in profits;

- protection and conservation of landscapes, recreational opportunities of forests, rivers and lakes;

- development of rural tourism self-organization and improvement of professional skills of personnel;

- use of local cultural and material heritage: architectural monuments, museums, gardens and parks, memorial sites and events, other objects of material culture of historical, artistic or other value;

- creation of new jobs in the countryside.

Effective development of rural tourism is possible if there are conditions for using all resource opportunities and sate support benefits.

The rural tourism industry does not require much government investment, has a multiplier effect and great social significance.

In Russia, rural tourism in Russia is gaining popularity. Russia has everything for the development of this area: a huge territory located in different climatic zones, an agricultural component in the national economy.

However, in many attractive regions, the infrastructure is poorly developed (bad roads, lack of quality places for catering, specialists and tourism experts).

Today, several regions of Russia having unique nature, rich cultural and material heritage, traditions of the rural population are successfully implementing rural tourism projects (Yaroslavl, Vologda and Kaluga regions, the republics of Buryatia, Altai, Khakassia). It is necessary to improve the legislation. National standards of the Russian Federation "Rural Guest Houses" and "Ecotourism" have been adopted.

However, in many attractive regions with an interesting base, the infrastructure is too poorly developed. Bad roads, lack of quality places for catering, lack of specialists and those who want to become experts in the field of tourism.

Today, several regions of Russia, counting on the unique nature, rich cultural and material heritage, traditions of the rural population, are successfully implementing projects in the field of rural tourism. These regions include the Yaroslavl, Vologda and Kaluga regions, the republics of Buryatia, Altai, Khakassia and many others. Work is underway to improve legislation: national standards of the Russian Federation "Rural Guest Houses" and "Ecotourism" have been adopted.

However, in general, the share of rural tourism in the total volume of tourism services remains low. The development of rural tourism is constrained by a number of restrictions: 
- lack of a systematic approach to the development and state support of rural tourism;

- imperfection and insufficiency of the existing legislative base;

- quality of rural tourism that does not meet potential expectations of Russian tourists due to the insufficient development of the material and technical base and the range of services offered; the lack of qualified personnel, insufficient quality of training programs and internships; the lack of the rural tourism infrastructure in some regions; limited access to rural tourism information.

This concept provides ways to solve these problems and ensure the rapid growth of rural tourism.

In the 1970s, in Europe there was a crisis in agriculture. This was due to the fact that products were not in demand and villagers rushed to cities. Thus, there was a need to offer rural residents other sources of income. One of the measures supporting the rural economy was agritourism. Rural tourism turned out to be in demand, rural infrastructure began to develop successfully, the unemployment rate decreased, incomes of rural residents increased.

In Russia, agritourism began to gain popularity in the 1990s. Tourism was considered as one of the ways to modernize agriculture.

Different countries have their own social and economic characteristics that influence the agritourism. In Western Europe, the rural tourism sector received an impetus for development due to the overproduction of agricultural products. In Russia, agricultural production and agritourism should develop together.

The expected results are as follows:

- By 2030, the volume of agritourism market will be 50 billion rubles;

- taking into account the agricultural tax rate, the estimated level of tax revenues will be 5 billion rubles. For other sectors of the macroeconomy, it will be 15-20 billion rubles. The return on public investment will be ensured;

- to achieve the goals and objectives of the concept, the amount of state support should be 12-15billion rubles for the entire period

- about 60,000 new jobs were created in the countryside $[2,10]$.

Consequently, alternative rural employment is one of the necessary conditions for reducing poverty and increasing efficiency in the agricultural sector. It is an obligatory measure as:

- non-agricultural activities are one of the most important sources of income for the rural population. Alternative employment is associated with an increase in the family budget, which means both the replacement of one type of activity with another, more profitable, and the diversification of family incomes. The impact of alternative employment on household incomes can be identified by studying sources of income;

- employment in the non-agricultural sector is characteristic of private households with low incomes;

- agriculture can be seen as a strategy of existence with the least degree of mechanization, the inability to use acquired resources, a low degree of commercialization;

- non-agricultural activities include self-employment and employment

In rural areas, non-agricultural, alternative employment is influenced by factors such as access to means of production (equipment, machinery, land), markets, information systems, physical and institutional infrastructure, etc. [6] Examples of alternative forms of are as follows: the revival of folk crafts; tourism; knitwear production; collection, processing and further sale of wild berries and mushrooms, etc.

By the level of labor income, there are

- alternative qualified, well-paid works (private lessons, medical services, sewing, construction and repair works, etc.);

- alternative not qualified works (small trade, shuttle business, provision of various services). They produce both very high and low incomes.

By the method of carrying out informal activities and generating income, there are:

- individually employed workers; employees and owners of small unregistered production units;

- unofficial employees;

- tax-protected activities of enterprises in the formal sector, which brings unaccounted income to employees;

- workers carrying out unaccounted activities in the formal sector.

By the status, there are workers in both the informal and formal sectors and those employed only in the informal sector.

A common feature that unites all types of alternative employment is instability associated with vocational training institutions, the social security system, poor legal protection, and limited access to the capital market [8].

In order to reduce the outflow of population from the village, in June 2019, a state program for the development of rural territories was approved. This program is aimed at improving housing conditions in rural areas and increasing the ratio of incomes of rural and urban population. An increase in the initial volume of financing is associated with extrabudgetary funds. It will amount to 1.4 trillion. rubles.

109 billion rubles will be allocated from the consolidated budgets. The largest decline is expected in 2020-2022: instead of 1 trillion rubles, 241.5 billion rubles will be allocated. In 2020 , the volume of financing will decrease from 227.8 to 96.4 billion rubles; in 2021 - from 362.7 to 78.4 billion rubles, 
and in 2022 - from 412.8 to 66.7 billion rubles. In the next three years, the reduction will not exceed 10-15 billion rubles. The total amount will be 1.2 trillion rubles.

Despite the reduced costs of many subprograms, the target indicators have changed unevenly. It is assumed that the share of rural and urban incomes will be $75.5 \%$ instead of $80 \%$ (67\% in 2017). The implementation will be affected by the reduced amount of funding of the employment project. The share of the comfortable housing project will decrease from 50 to $43.2 \%$ (32.6\% in 2017). Up to 122,000 families will be able to get soft loans to improve housing conditions by 2025 . However, the Ministry of Agriculture hopes to fulfill the main task of the state program - to stop the flow of population from villages. The main indicator of the program is the share of the rural population which should be at least $25.1 \%$ by 2025 [9].

\section{CONCLUSION}

In accordance with the law on the federal budget for 20202022 , changes were needed to bring funding into line. Due to the significant rural development potential, the ministry aims to increase the amount of funding. In the first year, the rural development program was supposed to affect territories where more than a million people live. At the beginning of 2020, the volume of money allocated to the regions was132 billion rubles. This exceeds the target volume of funding 1.7 times.

Assessing the rural labor market, it should be noted that official statistics does not reflect the real situation: the number of unemployed is underestimated, and the number of employed is overstated.

It is necessary to predict the development of labor resources, rural employment indicators, the development of basic scientific research, and analyze real unemployment indicators which are constantly changing.

\section{References}

[1] V.A. Bogdanovsky, "Employment in agrarian economy: theoretical and methodological aspects of research $=$ Employment in agrarian economy: theoretical-methodological aspects of examination", AIC: Econ., Manag., no. 1, pp. 75-80. 2016.

[2] L. Bondarenko, "Employment in the countryside and diversification of the rural economy", Agricult. Econ. of Russ., no. 1, pp. 71-76, 2011.

[3] L.V. Bondarenko, "Employment in rural areas and resource support of small business organizations by rural unemployed", Econ. of agricult. and processing enterprises, no. 12, pp. 58-62, 2011.

[4] I.B. Voskoboinikov, V. Gimpelson, "Labor productivity growth, structural shifts and informal employment in the Russian economy", Probl. of Econ., no. 11, 30-61, 2015.

[5] Official website of the Ministry of Health of the Russian Federation. Retrieved from: https://www.rosminzdrav.ru/ (accessed: 05/07/2020).

[6] V.G. Novikov, S.V. Zhubarkin, "Agrarian tourism as a factor of territorial development and diversification of the rural economy", AIC: Econ., Manag., no. 10, pp. 75-82, 2013.

[7] Official site of the Federal State Statistics Service of the Russian Federation. Retrieved from: http://www.gks.ru (accessed date: 05/12/2020).

[8] A.Yu. Pavlov, L.I. Malyuk, "Alternative employment as a factor in the sustainable development of rural territories", Econ. anal.: theory and pract., no. 29 , pp. 34-39, 2014.

[9] Forecast of the socio-economic development of the Russian Federation for 2018 and for the planning period of 2019 and 2020. Retrieved from: http://economy.gov.ru (accessed: 05/02/2020).

[10] Rural tourism, Russian Union of Travel Industry. Retrieved from: http://www.rostourunion.ru/vstuplenie_v_rst/sel_skiyi.html (accessed: 05/12/2020).

[11] L.T. Tatarova, "Employment of the rural population: regional aspect", Econ., Manag., no. 9, pp. 87-93, 2013.

[12] A.A. Fedchenko, N.V. Dorokhova, E.S. Dashkova, "Flexible employment: global, Russian and regional aspects", World Econ. and Int. Relat., vol. 62, no. 1, pp. 16-24, 2018. Retrieved from: http://dx.doi.org/10.20542/0131-2227-2018-62-1-16-24>

[13] A.V. Shmytkova, Rural tourism. Rostov-on-Don: Publ. House of the Southern Fed. Univer. (SFU), 2019, 116 p. Retrieved from: http://new.znanium.com/go.php? Id = 1088123 > (accessed: 05/12/2020). 